\title{
Quality assessment of spring water from the area of the Kysogóry Mts. in Świętokrzyski National Park in 2010
}

\author{
Michat Jasik $\bowtie$, Stanisław Małek \\ University of Agriculture in Krakow, Faculty of Forestry, Department of Forest Ecology, al. 29 Listopada 46, \\ 31-425 Kraków, Poland, phone: +4812 6625080, e-mail: michal.jasik@op.pl
}

\begin{abstract}
The study was conducted in the year 2010 in the Łysogóry Mts. in Świętokrzyski National Park. Spring water samples were collected in three rounds. The first round was carried out after the period of snowmelt (March/ April 2010), the second - after intensive rainfall (May 2010) and the third - when water levels were low (July 2010). The data set attained concerned conductivity, water $\mathrm{pH}$, and also concentrations of the foremost anions $\left(\mathrm{Cl}^{-}, \mathrm{NO}_{3}{ }^{-}, \mathrm{SO}_{4}{ }^{2-}\right)$ and cations $\left(\mathrm{NH}_{4}^{+}, \mathrm{Na}^{+}, \mathrm{K}^{+}, \mathrm{Ca}^{2+}, \mathrm{Mg}^{2+}\right)$. Spring water quality was assessed in line with Polish policy on groundwater (Regulation of the Minister of Environment of 23 July 2008, The results confirmed that spring water quality strongly depended on wet acid deposition and the geological structure. Tree species (fir and beech), exposition and soil types within the alimentation area did not influence water chemistry. Spring water were found in low quality classes according to Polish standards due to low water $\mathrm{pH}$ as well as high $\mathrm{NO}_{3}{ }^{-}$and $\mathrm{NH}_{4}^{+}$concentration.
\end{abstract}

\section{KeY WORDS}

springs, Świętokrzyski National Park, water quality, water chemistry

\section{INTRODUCTION}

Springs are very important elements of the natural environment, especially in the areas that are under legal protection. In order to better understand protected areas, one should pay particular attention to identifying water conditions, both quantitative and qualitative. Springs being natural groundwater outflows respond well to any changes that occur in natural ecosystems (Wolanin and Żelazny 2010), and therefore can be classified as important hydrogeological indicators. Recent climate change has contributed to the occurrence of extreme events such as droughts and floods, causing fluctuations in groundwater levels. Forest ecosystems play a very important role in the protection of aquatic environment and in climate change mitigation. In mountainous areas, and especially in national parks where conducting hydrogeological drilling is restricted, springs are an important element of groundwater studies (Humnicki 2007). The evaluation of spring waters quality is a fundamental analysis to study their physico-chemical properties (Małek and Krakowian 2009). Within Poland's area, spring water chemistry has been afore studied, and among others in: the Tatra Mountains (Żelazny et al. 2011), the Silesian Beskid Mts. (Astel et al. 2009; Małek et al. 2009, 2010), Pomerania (Mazurek 
2006) and in the Świętokrzyskie Mts. (Michalik 2008). The aim of the present research was to verify the following hypothesis:

- chemical quality of spring water from the Łysogóry Mts. is determined by the geological structure of drainage areas modified by seasonal changes of catchment water, level;

- differences in chemistry of spring waters depend on a level of massif hydration with other environmental factors such as geological structure, soil and species composition of tree stands.

\section{MAterial AND MEthods}

The study was conducted in the Łysogóry massif located in Świętokrzyski National Park, in the northern part of Świętokrzyskie Province (south-central Poland) (fig. 1). The geographical coordinates of the Łysogóry massif are: $50^{\circ} 50^{\prime}-50^{\circ} 55^{\prime} \mathrm{N}$ and $20^{\circ} 52^{\prime}-21^{\circ} 05^{\prime} \mathrm{E}$. Altitude difference between the Lysica peak (612 $\mathrm{m}$ a.s.1.) and the lowest point- located in the Pokrzywianka valley (225 m a.s.1.) - is $387 \mathrm{~m}$. The Lysogóry massif is built mainly of various types of hard quartzitic sandstones, quartz sandstones, siltstones and claystones - collectively quartzite of Łysogóry. The massif is approximately $300 \mathrm{~m}$ higher in position in relation to the area around and as a result affected by both local and distant sources of industrial pollution, especially those in the western and south-western directions (Kozłowski and Adwent 2011). Very high $\mathrm{SiO}_{2}$ content in cambrian quartzites and quartzite sandstones (98-99\%) and very low contents of $\mathrm{Ca}, \mathrm{Mg}$ and $\mathrm{P}$ predetermine extremely acidic nature of the rocks and their weathering products (Kowalkowski et al. 2001). Quartz sandstones collapse monoclinally toward the north, resulting in shorter and steeper slopes in massif northern side in comparison to cradle-shaped slopes in the southern side. The area where water samples were collected is covered by fir and beech forests.

Water samples from springs were collected over the vegetation season in 2010 during three measurement rounds: after snowmelt (30 March-3 April ), after intensive rainfall (27-31 May) and after rainless period (21-24 August). For chemical analyses and statistical tests there were taken into consideration only waters from the springs active in all three measurement

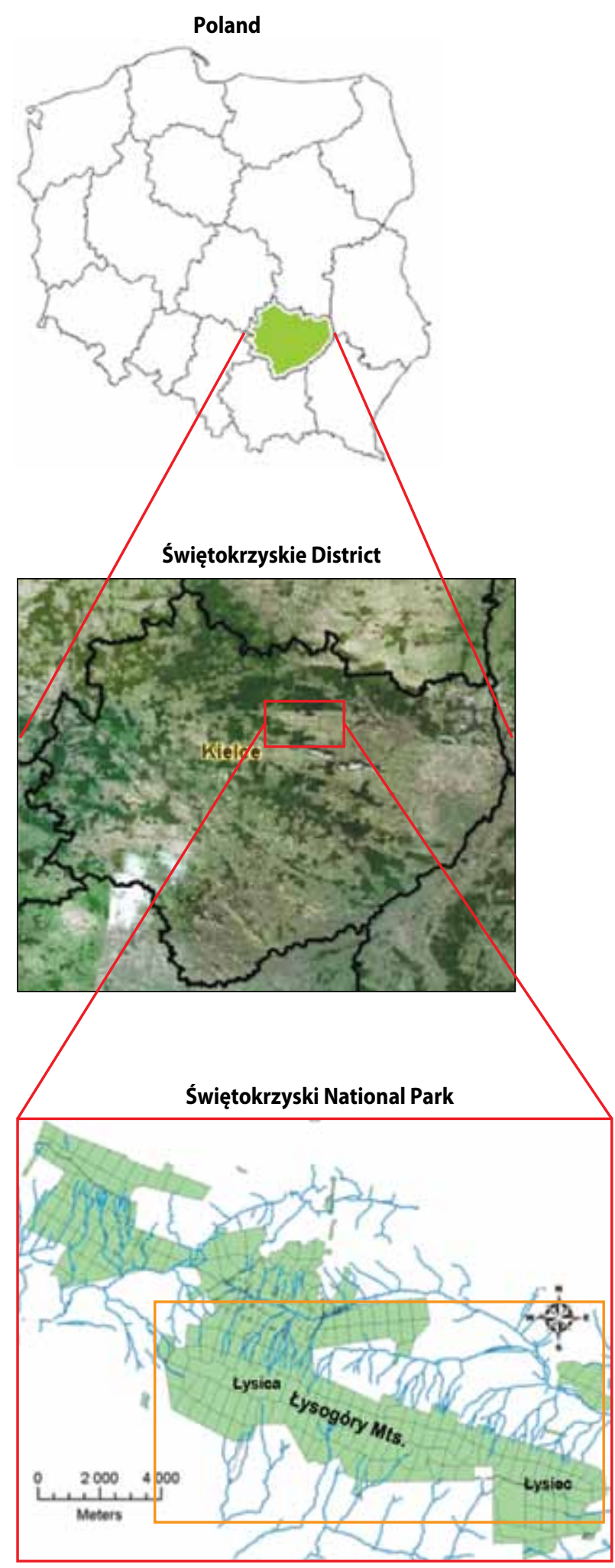

Fig. 1. Location of study area 
rounds -50 points (fig. 2). The water samples collected were analyzed in the chemical laboratory of the Forest Ecology Department, University of Agriculture in Kraków. Sample pH value (pH-meter Eijkelkamp 18.37) and electrolytic conductivity - EC (conductivity meter Eijkelkamp EC 18.34) were measured before filtering. The concentrations of: $\mathrm{Na}^{+}, \mathrm{NH}_{4}^{+}, \mathrm{K}^{+}, \mathrm{Ca}^{2+}, \mathrm{Mg}^{2+}, \mathrm{Cl}^{-}$, $\mathrm{NO}_{3}{ }^{-}$and $\mathrm{SO}_{4}{ }^{2-}$ in filtered samples were analyzed with Dionex -320 ion chromatograph.

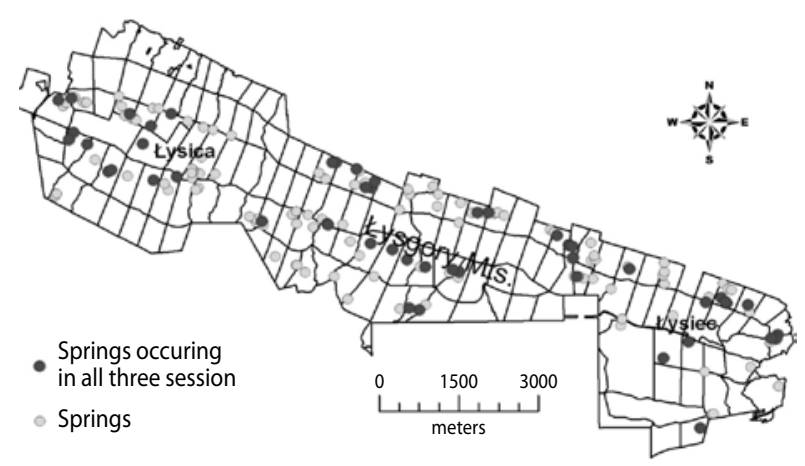

Fig. 2. Location of springs in the Łysogóry Mts. in Świętokrzyski National Park

Water quality was assessed in line with Polish law (Regulation of the Minister of Environment of 23 July 2008 on the criteria and method of assessment of the status of groundwater, Dz.U. 2008 No 143 art. 896).

The results were statistically analyzed using STATISTICA 9.1 software. The tests included calculations of means and standard deviations. Normal distribution of the data was tested with the Shapiro Wilk test. The distribution for each variable was not consistent with normal distribution, thus the Kruskal-Wallis test and Ward's method for hierarchical clustering were used in nonparametric comparisons.

\section{Results AND Discussion}

The classification of spring water quality in line with the Regulation of the Minister of Environment of 23 July 2008 is presented in tab. 1. The quality class I, was indicated only in 6 springs during the period of low water level. In the two other measurement rounds, there were not found springs with the quality equivalent to class I. The main factor causing quality drop was too low $\mathrm{pH}$ value in the waters observed. In the first measurement round only 3 springs indicated appropriate $\mathrm{pH}$ (pH 6.5-9.5 for I, II and III quality classes, respectively), however higher concentrations of $\mathrm{NH}_{4}^{+}$(max. $0.5 \mathrm{mg} / \mathrm{dm}^{3}$ for class I, $1 \mathrm{mg} / \mathrm{dm}^{3}$ for class II and 1.5 for class III) and $\mathrm{NO}_{3}{ }^{-}\left(\max 10 \mathrm{mg} / \mathrm{dm}^{3}\right.$ for class I and 25 for class II) decreased the quality of spring waters to class II. In the second measurement round carried out after intensive rainfalls, none of the samples indicated appropriate $\mathrm{pH}$ value, and additionally the concentration of $\mathrm{NH}_{4}{ }^{+}$ and $\mathrm{NO}_{3}{ }^{-}$allocated the springs investigated in class II. The best status of waters was observed in the period of low water level, when 6 springs were assigned to class I and 6 springs were assigned to class II. In this measurement round there were recorded higher $\mathrm{pH}$ values, however, 38 springs does not comply with these criteria.

The results of ion chromatography showed differences in chemical composition of water, depending on the sampling period. Waters collected from the springs in the third measurement round were characteristic of higher concentrations of $\mathrm{Na}^{+}, \mathrm{Mg}^{2+}, \mathrm{Ca}^{2+}, \mathrm{Cl}^{-}$, and definitely higher $\mathrm{pH}$ (tab. 2).

Ward's method (cluster analysis) grouped the springs in terms of water physico-chemical properties (fig. 3). However, except for the differences in chemical composition and $\mathrm{pH}$, a group significantly different in terms of natural conditions (soil, trees, location) was not found. The reason for the lack of relationship between the species composition and quality of spring

Tab. 1. Number of the points classified to each water class in each studied session with the pointed out the limited factors in line with the Regulation of the Minister of Environment of 23 July 2008 - standards for groundwater (Dz.U. 2008 No 143 art. 896 )

\begin{tabular}{|c|c|c|c|c|c|c|c|c|c|c|c|c|c|c|c|}
\hline \multirow{2}{*}{ Limiting factor } & \multicolumn{5}{|c|}{ Snowmelt } & \multicolumn{5}{|c|}{ Rainfall } & \multicolumn{5}{|c|}{ Dry period } \\
\hline & I & II & III & IV & V & I & II & III & IV & V & I & II & III & IV & $\mathrm{V}$ \\
\hline $\mathrm{NH}_{4}^{+}$ & & 41 & 4 & & & & 48 & & & & & 31 & 6 & & \\
\hline $\mathrm{NO}_{3}^{-}$ & & 20 & & & & & 14 & & & & 6 & 15 & & & \\
\hline $\mathrm{pH}$ & & & & 47 & & & & & 50 & & & & & 38 & \\
\hline
\end{tabular}



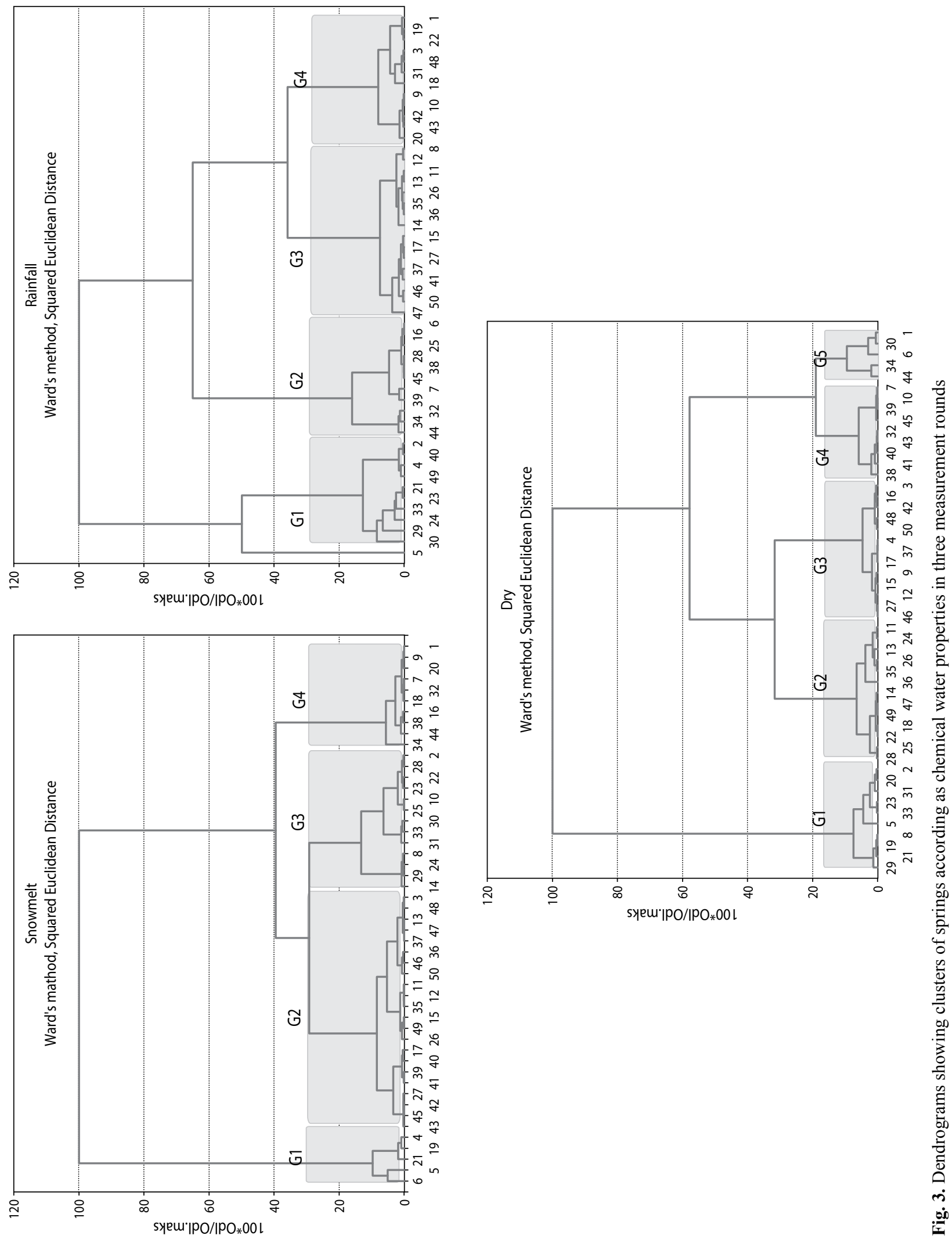
Tab. 2. Mean values and standard deviations of factors analyzed $\left(\mathrm{mg} / \mathrm{dm}^{3}\right)$

\begin{tabular}{|l|l|l|l|l|l|l|l|l|l|l|}
\hline \multicolumn{2}{|c|}{ Session } & $\mathrm{Na}^{+}$ & $\mathrm{NH}_{4}^{+}$ & $\mathrm{K}^{+}$ & $\mathrm{Mg}^{2+}$ & $\mathrm{Ca}^{2+}$ & $\mathrm{Cl}^{-}$ & $\mathrm{NO}_{3}^{-}$ & $\mathrm{SO}_{4}{ }^{2-}$ & $\mathrm{pH}$ \\
\hline \multirow{2}{*}{ Snowmelt } & mean & 1.45 & 0.79 & 0.72 & 2.05 & 7.30 & 4.62 & 8.61 & 33.90 & 5.03 \\
\cline { 2 - 12 } & st. dev. & 0.99 & 0.19 & 0.49 & 1.16 & 3.22 & 1.98 & 4.96 & 13.43 & 0.76 \\
\hline \multirow{2}{*}{ Rainfall } & mean & 1.52 & 0.69 & 0.74 & 2.00 & 7.08 & 4.48 & 7.64 & 34.99 & 4.88 \\
\cline { 2 - 12 } & st. dev. & 1.24 & 0.11 & 0.53 & 0.95 & 3.74 & 1.86 & 4.86 & 14.13 & 0.57 \\
\hline \multirow{2}{*}{ Dry } & mean & 2.82 & 0.76 & 0.98 & 2.43 & 8.02 & 5.58 & 7.99 & 24.20 & 5.67 \\
\cline { 2 - 11 } & st. dev. & 1.06 & 0.22 & 0.71 & 0.91 & 2.64 & 2.09 & 5.51 & 15.39 & 0.95 \\
\hline
\end{tabular}

waters lies in the fact that the species of trees growing at the outflow of springs are not always representative for the whole area. A broader view on water collection area - the alimentation area (tank maintenance) brings one closer to knowledge on the impact of environmental conditions on the quality of springs.

The Świętokrzyskie Mts. is the area highly elevated over the surrounding region. This increases the intensity of imission and impacts on pedo- and lithosphere of the area even by long-range emitters $(>100 \mathrm{~km})$ (Jóźwiak and Kowalkowski 2003). The latter include the Upper Silesian Industrial Region, Agglomeration of Kraków and Bełchatów Brown Coal Mine. Winds carry high levels of nitrate and sulphate ions which are deposited both in the form of dry deposition and wet acid deposition (Jóźwiak and Kozłowski 2004). The low $\mathrm{pH}$ value of precipitation in the Łysogóry Mts. together with further acidifying effects of tree crowns and forest litter affect soils (Kozłowski and Adwent 2011) as well as they impact mountain springs causing changes in water chemical properties.

Spring waters collected in the last round (rainless period) were characteristic of higher $\mathrm{pH}$ value as well as concentrations of $\mathrm{Na}^{+}, \mathrm{Mg}^{2+}, \mathrm{Ca}^{2+}, \mathrm{Cl}^{-}$(tab. 3). In the rainless period there were observed low water conditions and no effect of precipitation on the spring waters analyzed.. At this point, spring waters are mainly supplied by underground waters (not with rain), which may result in higher concentrations of the ions. The greater impact on chemistry of spring waters might have had local cambrian shale layers, since they are slightly richer in magnesium and sodium than basic rocks that build the main massif (Kowalkowski et al. 2001). Besides, research conducted in the Tatra Mts. (Tatra National Park) showed key effects of the geological structure on spring water chemistry, especially during the period of low water levels (Żelazny et al. 2011). Likewise, the impact of geology on spring water chemical composition was stressed by Michalik et al. (2008).

Tab. 3. Kruskal-Wallis test results for factors analyzed

\begin{tabular}{|l|c|c|c|c|}
\hline \multirow{2}{*}{ Factor } & \multicolumn{3}{|c|}{ Rang sum } & \multirow{2}{*}{} \\
\cline { 2 - 4 } & $\begin{array}{c}\text { snowmelt } \\
\mathrm{a}\end{array}$ & $\begin{array}{c}\text { rainfall } \\
\mathrm{b}\end{array}$ & $\begin{array}{c}\text { dry period } \\
\mathrm{c}\end{array}$ & $\mathrm{p}$ \\
\hline $\mathrm{Na}^{+}$ & 2733.5 & 2793.0 & $5798.5^{\text {a.b }}$ & $\mathrm{p}<0.001$ \\
\hline $\mathrm{NH}_{4}^{+}$ & $4504.5^{\text {b.c }}$ & 3255.5 & 3565.0 & $\mathrm{p}=0.013$ \\
\hline $\mathrm{K}^{+}$ & 3433.5 & 3487.5 & 4404.0 & $\mathrm{p}=0.043$ \\
\hline $\mathrm{Mg}^{2+}$ & 3444.0 & 3448.5 & 4432.5 & $\mathrm{p}=0.032$ \\
\hline $\mathrm{Ca}^{2+}$ & 3693.5 & 3347.5 & 4284.0 & $\mathrm{p}=0.093$ \\
\hline $\mathrm{Cl}^{-}$ & 3396.0 & 3146.0 & $4783.0^{\text {a.b }}$ & $\mathrm{p}<0.001$ \\
\hline $\mathrm{NO}_{3}{ }^{-}$ & 4050.5 & 3528.5 & 3746.0 & $\mathrm{p}=0.483$ \\
\hline $\mathrm{SO}_{4}{ }^{2-}$ & 4222.5 & 4281.5 & $2821.0^{\text {a.b }}$ & $\mathrm{p}<0.001$ \\
\hline $\mathrm{pH}^{2-}$ & 3355.5 & 3078.0 & $4891.5^{\text {a.b }}$ & $\mathrm{p}<0.001$ \\
\hline $\mathrm{EC}$ & 4180.0 & 4218.5 & $2926.5^{\text {a.b }}$ & $\mathrm{p}<0.003$ \\
\hline
\end{tabular}

The values in grey cells indicate statistically significant differences.

According to Kowalkowski et al. (2001) in soil environment of the Łysogóry massif, there is no possibility of returning to balanced circulation of ions and even a small influx of acidic components will result in further increasing acidity of ground - and surface water.

\section{Conclusions}

1. Spring waters in the Łysogóry Mts. are of poor quality in keeping with Polish Minister of Environment regulations on groundwater. Only a few samples had $\mathrm{pH}$ values and the content of $\mathrm{NO}_{3}{ }^{-}$and $\mathrm{NH}_{4}$ suitable for water of good quality. 
2. The main impact on the quality of water has a $\mathrm{pH}$ value and high concentrations of ion $\mathrm{NH}_{4}{ }^{+}$and $\mathrm{NO}_{3}{ }^{-}$ due to the geological structure of the Łysogóry massif (mainly acidic quartzite and quartzitic sandstones) and the dry and wet deposition of acidic substances.

3. Higher quality of spring waters was recorded in the period of low water levels - with limited inflow of pollutants from precipitation.

4. Seasonal dynamics of electrolytic conductivity inversely proportional to the $\mathrm{pH}$ value was indicated. Minimum conductivities were noted during low massif hydration with maximum $\mathrm{pH}$ values observed.

5. Tree species (fir and beech), exposition and soil types within the alimentation area did not influence spring water chemistry.

\section{Acknowledgements}

This study was financially supported by Statutory financial support of Ministry of Science and Higher Education RP (DS-3420) in 2012, Department of Forest Ecology University of Agriculture in Krakow). This paper was developed during the 60th anniversary of the University of Agriculture in Krakow, Poland.

\section{References}

Astel A., Małek S., Krakowian K. 2009. Multivariate exploration and classification applied to the chemical composition of spring waters in sanctuary forest areas. International Journal of Environmental Analytical Chemistry, 89, 597-620.

Astel A., Małek S., Makowska S. 2008. Effect of environmental conditions on chemical profile of stream water in sanctuary forest area. Water, Air, and Soil Polllution, 195, 137-149.

Humnicki W. 2007. Hydrogeologia Pienin. Wydawnictwo Uniwersytetu Warszawskiego.

Jóźwiak M., Kowalkowski A. 2003. Implementation of the Integrated Environmental Monitoring in the Świętokrzyski Region in the $10^{\text {th }}$ Anniversary of Its Inauguration (in Polish). Regionalny Monitoring Środowiska Przyrodniczego, 4, 9-22.
Jóźwiak M., Kozłowski R. 2004. Transformation of precipitationin chosen geoecosystems in the Świętokrzyskie Mountains (in Polish). Regionalny Monitoring Środowiska Przyrodniczego, 5, 199-217.

Kowalkowski A., Jóźwiak M., Kozłowski R. 2001. Pedogenical factors of water acidification in forest ecosystem of Świętokrzyski National Park (in Polish). Pedogeniczne czynniki procesów zakwaszania wód w ekosystemie leśnym Świętokrzyskiego Parku Narodowego. In: Integrated Monitoring of Environment (eds.: M. Jóźwiak, A. Kowalkowski), Biblioteka Monitoringu Środowiska, Kielce, 253-270.

Kozłowski R., Adwent E. 2011. Przestrzenna zmienność wybranych właściwości fizyczno-chemicznych gleb w centralnej części Gór Świętokrzyskich (Spatial variability of selected physico-chemical soil properties in the central part of the Świętokrzyskie Mountains). Monitoring Środowiska Przyrodniczego, 12, 93-101.

Małek S., Astel A., Krakowian K., Opałacz J. 2010. Quality assessment of spring water from the area of Skrzyczne and Barania Góra mountains (in Polish). Sylwan, 154, 499-505.

Małek S., Krakowian K. 2009. Analysis of usability for drinking of Zimnik and Czyrna spring waters in Silesian Beskid Mts (in Polish). Ochrona Środowiska i Zasobów Naturalnych, 38, 245-253.

Mazurek M. 2006. Factors affecting the chemical composition of groundwater outflows in the southern part of the Parsęta drainage basin (West Pomerania) (in Polish). Przeglad Geologiczny, 56, 131-139.

Michalik A. 2008. The use of chemical and cluster analysis for studying spring water quality in Świętokrzyski National Park. Polish Journal of Environmental Studies, 17 (3), 357-362.

Regulation of the Minister of Environment of 23 July 2008. Dz.U. 2008 Nr 143 poz. 896.

Wolanin A., Żelazny M. 2010. Seasonal changes in spring water chemistry in the Chochołowski and Kościeliski stream catchments (Tatra Mts.) in 2009. In: Water in the geographical study (eds.: T. Ciupa, R. Suligowski). Instytut Geografii Uniwersytetu Jana Kochanowskiego, Kielce, 339-347.

Żelazny M., Astel A., Wolanin A., Małek S. 2011. Spatiotemporal dynamics of spring and stream water chemistry in a high-mountain area. Environmental Pollution, 159, 1048-1059. 